\title{
Low cholesteryl ester transfer protein and phospholipid transfer protein activities are the factors making tree shrew and beijing duck resistant to atherosclerosis
}

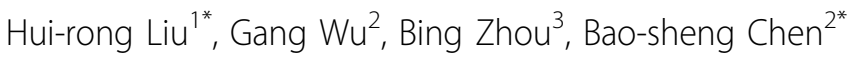

\begin{abstract}
Background: Tree shrew and beijing duck are regarded as animal models resistant to atherosclerosis (AS). This study was carried out to discover the potential mechanism.

Methods: Blood samples were collected from healthy men and male animals. Plasma lipid profile and activities of cholesteryl ester transfer protein (CETP) and phospholipid transfer protein (PLTP) were measured, compared and analyzed in human, tree shrew, and Beijing duck.

Results: The results showed that there were species differences on plasma lipid profile and activities of CETP and PLTP in the three species. Compared with human, tree shrew and beijing duck had higher high density lipoprotein cholesterol (HDL-C)/total cholesterol (TC) and HDL-C/low density lipoprotein cholesterol (LDL-C) ratios, but lower CETP and PLTP activities. In the three species, CETP and PLTP activities were negatively related with the ratio of HDL-C/LDL-C.

Conclusions: The present study suggested that low plasma CETP and PLTP activities may lead to a high HDL-C/ LDL-C ratio and a high resistance to AS finally in tree shrew and beijing duck. Moreover, low PLTP activity may also make the animals resistant to AS by the relative high vitamin E content of apoB-containing lipoproteins and high anti-inflammatory and antioxidative properties of HDL particles. A detailed study in the future is recommended.
\end{abstract}

\section{Background}

Cholesteryl ester transfer protein (CETP) and phospholipid transfer protein (PLTP) are two important factors to transfer lipids in lipoprotein metabolism. CETP transfers cholesteryl ester from high density lipoprotein (HDL) to lipoproteins of lower density, partly in exchange for triglycerides. PLTP promotes the transfer of phospholipids and free cholesterol between lipoproteins $[1,2]$. It is reported that CETP and PLTP activities are closely related to atherosclerosis (AS) [1,2].

\footnotetext{
* Correspondence: Ihz17@yahoo.com.cn; bschen@ibms.pumc.edu.cn ${ }^{1}$ College of Life Sciences, Inner Mongolia Agricultural University, Hohhot 010018, China

${ }^{2}$ National Laboratory of Medical Molecular Biology, Institute of Basic Medical Sciences, Chinese Academy of Medical Sciences, Peking Union Medical College, Beijing 100005, China

Full list of author information is available at the end of the article
}

Some vertebrate species can be defined as two distinct groups with low or high atherosclerosis susceptibility [3]. Cat, dog, mouse and rat belong to the 'resistant' group, while chicken, pig, rabbit and man belong to the 'susceptible' group. It is showed that plasma lipids transfer activities are significantly different between the two groups, which exert different effects on the atherogenicity of the plasma lipoprotein profile and therefore make the species resistant or susceptible to atherosclerosis [4].

Tree shrew and beijing duck are regarded as animal models resistant to AS [5,6]. It is documented that plasma HDL still remains a relative high level in these animals and no typical atherosclerotic plaques are found in the artery wall on a high cholesterol diet. These data point out a high resistance of tree shrew and beijing

\section{Biomed Central}

(c) 2010 Liu et al; licensee BioMed Central Ltd. This is an Open Access article distributed under the terms of the Creative Commons Attribution License (http://creativecommons.org/licenses/by/2.0), which permits unrestricted use, distribution, and reproduction in any medium, provided the original work is properly cited. 
duck to AS, however, the potential mechanism still remains unknown.

In this study, we measured and compared plasma lipid profile and activities of CETP and PLTP in human, tree shrew and beijing duck, which might provide some helpful insights on the anti-atherosclerotic mechanism in the two species.

\section{Methods}

\section{Blood samples}

Blood samples from 20-30-year old normolipidemic men were provided by Central Blood Bank of Peking Union Medical College Hospital, and blood samples from 6month old male tree shrews were provided by Kunming Institute of Zoology, Chinese Academy of Science. Blood samples from 4-month old male beijing ducks were generous gifts of Prof. Suisheng Hou [Institute of Animal Science (IAS), Chinese Academy of Agricultural Sciences (CAAS)]. The blood samples were collected into EDTAcontaining glass tubes by veno-puncture. Plasma was separated by a 5 -min centrifugation at $3000 \mathrm{~g}$ at $4^{\circ} \mathrm{C}$ and was immediately stored at $-70^{\circ} \mathrm{C}$ for further analysis. The experiments were performed in accordance with the guidelines of the National Institutes of Health (Bethesda, MD, USA) and Peking Union Medical College for the humane treatment of laboratory animals. All efforts were made to minimize the animals' suffering.

\section{Plasma lipid assays}

Total plasma cholesterol (TC) was measured using CHOD-PAP method (cholesterol oxidase peroxidasephenol 4 amino phenazon), and plasma triglyceride (TG) was measured using the GPO-PAP method (Glycerol phosphate oxidase-phenol 4 amino phenazon) (Zhongshengbeikong Biotech Co., Ltd, Beijing, China). High density lipoprotein cholesterol (HDL-C) and low density lipoprotein cholesterol (LDL-C) were determined by homogeneous method [synthetic polymer/detergent HDL-C assay (SPD) method for HDL-C and surfactant LDL-C assay (SUR) method for LDL-C] (Daiichi Pure Chemicals Co. LTD., Japan).

\section{Plasma CETP and PLTP activity}

Plasma CETP activity was measured using an assay kit following the manufacturer's instruction (BioVision, Mountain View, CA). Briefly, $3 \mu \mathrm{l}$ of plasma sample (as the source of CETP) was added to the reaction mixture containing a fluorescent self-quenched neutral lipid as the donor molecule and an acceptor molecule. A CETPmediated transfer of the fluorescent neutral lipid to the acceptor molecule resulted in an increase in fluorescence, which was read in a fluorescence plate reader at excitation $465 \mathrm{~nm}$ and emission $535 \mathrm{~nm}$. CETP activity was expressed as pico-mole of neutral lipid transferred per microlitre plasma per hour. Samples were run in triplicate. All CETP analyses were conducted in the same day to decrease variability. Plasma PLTP activity was determined using a PLTP activity kit (Bio Vision). The protocol for the PLTP activity kit was similar to that for the CETP activity kit.

\section{Statistical analysis}

Data were analyzed using SPSS for Windows XP. All descriptive data collected were expressed as mean \pm standard deviation (SD) and the Student ' $t$ ' test was used for analysis. Values of $\mathrm{P}<0.05$ were regarded as statistically significant.

\section{Results}

\section{Plasma Lipid concentrations}

Lipid concentrations were measured in total plasma of human, tree shrew and beijing duck (Table 1). In the three species, levels of TC, TG, and HDL-C were highest in beijing duck, whereas levels of LDL-C were highest in human. Plasma HDL-C/TC and HDL-C/LDL-C ratios were higher in tree shrew and Beijing duck than in human (Table 2).

\section{Plasma cholesteryl ester transfer activity}

As described in section 2, cholesteryl ester transfer activity among the three species was evaluated by using CETP activity assay kit (Table 2). Cholestryl ester transfer rates could be measured in all the studied species. Plasma CETP activity in human was highest among the three species, about $59.7 \pm 10.5 \mathrm{pmol} / \mu \mathrm{l} / \mathrm{h}$. Plasma CETP activities in beijing duck and tree shrew were greatly lower than that in human, respectively $26.1 \pm 5.6$ and $23.8 \pm 4.4 \mathrm{pmol} / \mu \mathrm{l} / \mathrm{h}$. In the three species, CETP activity was negatively related with the ratio of HDL-C/ LDL-C ( $r=-0.96063)$ (Fig. 1).

\section{Plasma phospholipid transfer activity}

Plasma PLTP activity was determined by using PLTP activity assay kit (Table 2). Plasma PLTP activity in human was about $127.1 \pm 18.7 \mathrm{pmol} / \mu \mathrm{l} / \mathrm{h}$, dramatically higher than that in beijing duck and tree shrew (respectively $80.8 \pm 7.8$ and $63.2 \pm 12.7 \mathrm{pmol} / \mu \mathrm{l} / \mathrm{h}$ ). In the three species, PLTP activity was also negatively related with the ratio of HDL-C/LDL-C ( $r=-0.99763)$ (Fig. 2).

\section{Discussion}

In our study, compared with human, tree shrew and beijing duck had high HDL-C/TC and extremely high HDL-C/LDL-C ratios. In human, the HDL-C level was lower than the LDL-C level. The HDL-C/LDL-C ratio was about 0.60 . However, in tree shrew and beijing duck, the HDL-C level was greatly higher than the LDL$\mathrm{C}$ level. The HDL-C/LDL-C ratio even reached to 2.7 in 
Table 1 Plasma lipid concentrations in human, beijing duck and tree shrew

\begin{tabular}{lccccc}
\hline Species & $\mathbf{n}$ & $\mathbf{T C}(\mathbf{m g} / \mathbf{d l})$ & TG(mg/dl) & HDL-C(mg/dl) & LDL-C(mg/dl) \\
\hline Human & 9 & $137.75 \pm 30.26$ & $63.75 \pm 22.59$ & $47.38 \pm 9.05$ & $78.25 \pm 24.70$ \\
Beijing duck & 12 & $166.27 \pm 30.38$ & $268.82 \pm 54.57$ & $83.45 \pm 15.96$ & $42.91 \pm 12.20$ \\
Tree shrew & 9 & $66.44 \pm 9.02$ & $88.22 \pm 16.39$ & $29.11 \pm 5.16$ & $11.56 \pm 3.00$ \\
\hline
\end{tabular}

The values are mean \pm S.D.

tree shrew and 1.99 in beijing duck. It's well known that HDL-C is positively and LDL-C is negatively related with cardiovascular disease [7-9]. When too much LDL$\mathrm{C}$ circulates in the blood, it can pass from the blood into the arterial wall where it may be oxidised and engulfed by macrophages forming foam cells. Thereafter, a complex interplay of cell necrosis, smooth muscle recruitment and collagen deposition leads to the development of atherosclerotic plaques. However, HDL is involved in the reverse transport of cholesterol from the peripheral tissues to the liver, thereby reducing the uptake of cholesterol by macrophages and providing a protective effect against atherosclerosis. It also has antiinflammatory, antioxidant, or other effects on the arterial wall. Therefore, to reduce the risk of cardiovascular disease, many strategies have been adopted to decrease the circulating LDL-C level and increase HDL-C level. Our study demonstrated that tree shrew and beijing duck had very high HDL-C level but low LDL-C level, which might be the reason why the two species were resistant to AS.

It is reported that mean CETP activity is markedly lower in the 'resistant' group than in the 'susceptible' group, but PLTP activity is higher in the 'resistant' group than in the 'susceptible' group [4]. In accordance with the previous findings, in our study, as the species resistant to AS, tree shrew and beijing duck had dramatically lower plasma CETP activity than human, the species susceptible to AS. However, PLTP activity in the two species was also greatly lower than that in human, which was significantly different from the previous report [4]. This may be because of the species differences. Furthermore, in the three species, CETP and PLTP activities were negatively related with the ratio of HDL-C/LDL-C, not as reported that CETP activity was inversely correlated with HDL-C/ TC ratio [10]. CETP and PLTP are two important factors to transfer lipids in lipoprotein metabolism. CETP transfers cholesteryl ester from HDL to lipoproteins of lower density, partly in exchange for triglycerides. PLTP promotes the transfer of phospholipids and free cholesterol between lipoproteins [1,2]. Much research shows that the deficiency or decrease of CETP activity can lead to an increase in HDL-C, a decrease in LDL-C, and a lower incidence of stroke and coronary heart disease (CHD) [11-13]. However, the increase of CETP activity decreases the HDL-C level and increases the LDL-C level and atherosclerosis [14-16]. Although there are some contrary results too $[17,18]$, most of the studies seem to suggest that the partial inhibition of CETP appear to provide a reduction in atherosclerosis and CHD risk. Numerous in vivo studies show that an increase in plasma PLTP activity is associated with decreased HDL-C level, increased hepatic VLDL secretion and increased atherosclerotic lesion development [19-25]. In addition to its effect on HDL-C level and VLDL secretion, PLTP can also influence the atherogenicity of plasma lipoproteins by decreasing the vitamin $\mathrm{E}$ content of apoB-containing lipoproteins and affecting the anti-inflammatory and antioxidative properties of HDL particles, which results in increased susceptibility to AS $[23,24]$. On the contrary, PLTP deficiency results in markedly decreased atherosclerosis by a decrease in the production and levels of apoB-containing lipoprotein, an increase in their vitamin E content, and a decrease in their susceptibility to oxidation $[23,26]$. It is demonstrated that pronounced higher CETP and PLTP activities can lead to a marked decrease in HDL-C levels that is due to hypercatabolism [1,27-29] and an increase in LDL-C levels that is due to an increase in transfer of CE from HDL to LDL and production of apoB-containing lipoprotein $[1,26,30,31]$. In tree shrew and beijing duck, low CETP and PLTP activities might cause a low catabolism of HDL-C and a decrease in production of apoB-containing lipoprotein, which led to a relative high plasma level of HDL-C and low level of

Table 2 Activities of plasma CETP and PLTP and ratios of HDL-C/TC and HDL-C/LDL-C in human, beijing duck and tree shrew

\begin{tabular}{lccccc}
\hline Species & $\mathbf{n}$ & $\begin{array}{c}\text { CETP activity } \\
(\mathbf{p m o l} / \boldsymbol{\mu l} / \mathbf{h})\end{array}$ & $\begin{array}{c}\text { PLTP activity } \\
(\mathbf{p m o l} / \boldsymbol{\mu l} / \mathbf{h})\end{array}$ & HDL-C/TC & HDL-C/LDL-C \\
\hline Human & 9 & $59.7 \pm 10.5$ & $127.1 \pm 18.7$ & $0.33 \pm 0.07$ & $0.60 \pm 0.24$ \\
Beijing duck & 12 & $26.1 \pm 5.6$ & $80.8 \pm 7.8$ & $0.50 \pm 0.03$ & $1.99 \pm 0.37$ \\
Tree shrew & 9 & $23.8 \pm 4.4$ & $63.2 \pm 12.7$ & $0.44 \pm 0.05$ & $2.70 \pm 1.01$ \\
\hline
\end{tabular}

The values are mean \pm S.D. of three independent experiments. 


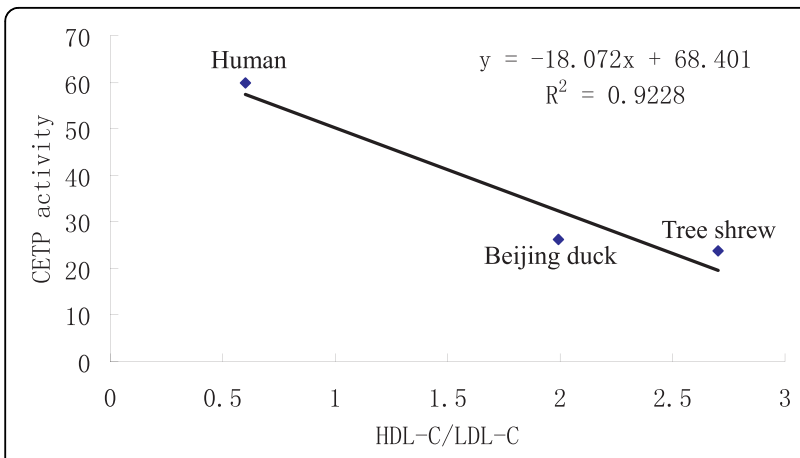

Figure 1 Relationship between the CETP activity and the ratio of HDL-C/LDL-C.

LDL-C and at last a high resistance to AS. Moreover, low PLTP activity may also make the animals resistant to AS by the relative high vitamin $\mathrm{E}$ content of apoB-containing lipoproteins and high anti-inflammatory and antioxidative properties of HDL particles. Of course, these details need to be studied further in the future.

Atherosclerotic cardiovascular disease (CVD) is the leading cause of morbidity and mortality in the industrialized world. The blood concentrations of the lipoprotein cholesterol fractions are closely related to the incidence of CVD. Many attempts have been made to control the blood lipoprotein cholesterol concentrations by regulating the activities of those enzymes involved in the lipoprotein metabolism. Therefore, the completion of our work may provide some helpful insights on the clinical treatment of human AS in the future.

\section{Conclusions}

The present study suggested that low plasma CETP and PLTP activities may lead to a high HDL-C/LDL-C ratio and a high resistance to AS finally in tree shrew and beijing duck. Moreover, low PLTP activity may also make the animals resistant to AS by the relative high vitamin $\mathrm{E}$ content of apoB-containing lipoproteins and high anti-

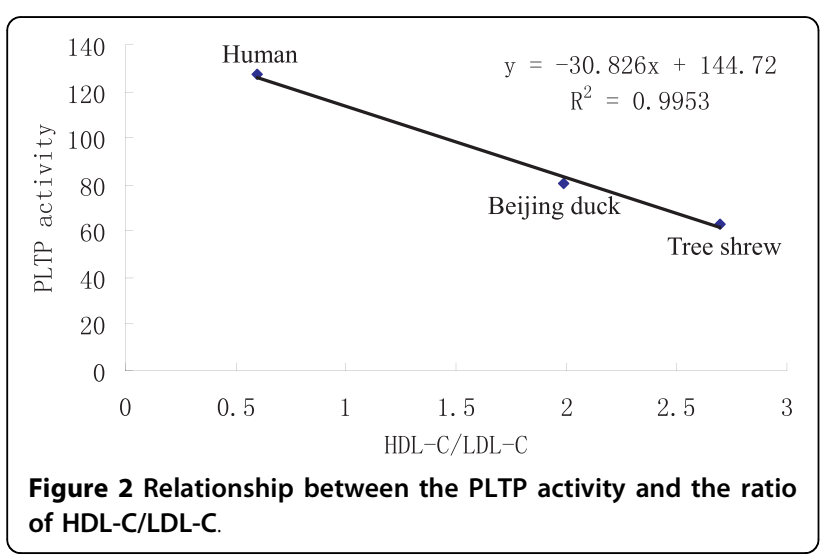

inflammatory and antioxidative properties of HDL particles. A detailed study in the future is recommended.

\section{Acknowledgements}

This work was supported by the Major State Basic Research Development Program of China (973 Program) (Grant No. 2006 CB 503801), the National Natural Science Foundation of China (Grant Nos. 39770168) and the Doctor Research Fund from Inner Mongolia Agricultural University (No. BJ05-34). We would like to thank Central Blood Bank of Peking Union Medical College Hospital and Mr. Shui-sheng Hou for providing blood samples of human and beijing duck.

\section{Author details}

${ }^{1}$ College of Life Sciences, Inner Mongolia Agricultural University, Hohhot 010018, China. ${ }^{2}$ National Laboratory of Medical Molecular Biology, Institute of Basic Medical Sciences, Chinese Academy of Medical Sciences, Peking Union Medical College, Beijing 100005, China. ${ }^{3}$ Beijing Center for ADR Monitoring, Beijing 100011, China.

\section{Authors' contributions}

HRL was the main investigator, conceived the study, carried out experiments, collected the data, and drafted the manuscript. BSC supervised the research and contributed to all aspects of the study. GW and BZ was advisor of the study and helped in analysis and interpretation. All authors read and approved the final manuscript.

\section{Competing interests}

The authors declare that they have no competing interests.

Received: 20 August 2010 Accepted: 12 October 2010 Published: 12 October 2010

\section{References}

1. Quintão EC, Cazita PM: Lipid transfer proteins: past, present and perspectives. Atherosclerosis 2010, 209:1-9.

2. Masson D, Jiang XC, Lagrost $L$, Tall AR: The role of plasma lipid transfer proteins in lipoprotein metabolism and atherogenesis. J Lipid Res 2009, 50:S201-206.

3. Liu M, Bagdade JD, Subbaiah PV: Specificity of lecithin:cholesterol acyltransferase and atherogenic risk: comparative studies on the plasma composition and in vitro synthesis of cholesteryl esters in 14 vertebrate species. J Lipid Res 1995, 36:1813-1824.

4. Guyard-Dangremont V, Desrumaux C, Gambert P, Lallemant C, Lagrost L: Phospholipid and cholesteryl ester transfer activities in plasma from 14 vertebrate species. Relation to atherogenesis susceptibility. Comp Biochem Physiol B Biochem Mol Biol 1998, 120:517-525.

5. She MP, Lu YZ, Xia RY, Wang ZL, Lv SH, An WM, Zhao SM, Liu LS, Liu PM, Guo SM, Liang P, Tao BW: The role of a-lipoprotein in preventing atheromatous plaques developed in tree shrew assoxiating with induced hypercholesterinemia. ZhongHuaYaoLiXueZaZhi 1982, 11:23-28.

6. Wang KQ, Li ZG, Hao QL, He JL, Li XZ, Zhang HZ, Tang JJ, Wu G, Chen BS, Wang JM, Xue H, Hu YM: The differences of serum cholesterol and lipoproteins in animals susceptible and nonsusceptible to atherosclerosis. Proc Chin Acad Med Sci Peking Union Med Coll 1990, 5:112-119.

7. Nicholls SJ: Relationship between LDL, HDL, blood pressure and atheroma progression in the coronaries. Curr Opin Lipidol 2009, 20:491-496.

8. Hausenloy DJ, Yellon DM: Enhancing cardiovascular disease risk reduction: raising high-density lipoprotein levels. Curr Opin Cardiol 2009, 24:473-482

9. Badimón JJ, Ibáñez B: Increasing high-density lipoprotein as a therapeutic target in atherothrombotic disease. Rev Esp Cardiol 2010, 63:323-333.

10. Tsutsumi K, Hagi A, Inoue Y: The relationship between plasma high density lipoprotein cholesterol levels and cholesteryl ester transfer protein activity in six species of healthy experimental animals. Biol Pharm Bull 2001, 24:579-581.

11. Brown ML, Inazu A, Hesler CB, Agellon LB, Mann C, Whitlock ME, Marcel YL, Milne RW, Koizumi J, Mabuchi H: Molecular basis of lipid transfer protein 
deficiency in a family with increased high-density lipoproteins. Nature 1989, 342:448-451.

12. Inazu A, Brown ML, Hesler CB, Agellon LB, Koizumi J, Takata K, Maruhama Y, Mabuchi H, Tall AR: Increased high-density lipoprotein levels caused by a common cholesteryl-ester transfer protein gene mutation. $N$ Engl J Med 1990, 323:1234-1238.

13. Thompson A, Di Angelantonio E, Sarwar N, Erqou S, Saleheen D, Dullaart RP, Keavney B, Ye Z, Danesh J: Association of cholesteryl ester transfer protein genotypes with CETP mass and activity, lipid levels, and coronary risk. JAMA 2008, 299:2777-2788.

14. Plump AS, Masucci-Magoulas L, Bruce C, Bisgaier CL, Breslow JL, Tall AR: Increased atherosclerosis in ApoE and LDL receptor gene knock-out mice as a result of human cholesteryl ester transfer protein transgene expression. Arterioscler Thromb Vasc Biol 1999, 19:1105-1110.

15. Westerterp M, van der Hoogt CC, de Haan W, Offerman EH, DallingaThie GM, Jukema JW, Havekes LM, Rensen PC: Cholesteryl ester transfer protein decreases high-density lipoprotein and severely aggravates atherosclerosis in APOE*3-Leiden mice. Arterioscler Thromb Vasc Biol 2006, 26:2552-2559

16. Tsai MY, Johnson C, Kao WH, Sharrett AR, Arends VL, Kronmal R, Jenny NS, Jacobs DR Jr, Arnett D, O'Leary D, Post W: Cholesteryl ester transfer protein genetic polymorphisms, HDL cholesterol, and subclinical cardiovascular disease in the Multi-Ethnic Study of Atherosclerosis. Atherosclerosis 2008, 200:359-367.

17. Hayek T, Masucci-Magoulas L, Jiang X, Walsh A, Rubin E, Breslow JL, Tall AR: Decreased early atherosclerotic lesions in hypertriglyceridemic mice expressing cholesteryl ester transfer protein transgene. J Clin Invest 1995, 96:2071-2074

18. Föger B, Chase M, Amar MJ, Vaisman BL, Shamburek RD, Paigen B, FruchartNajib J, Paiz JA, Koch CA, Hoyt RF, Brewer HB Jr, Santamarina-Fojo S: Cholesteryl ester transfer protein corrects dysfunctional high density lipoproteins and reduces aortic atherosclerosis in lecithin cholesterol acyltransferase transgenic mice. J Biol Chem 1999, 274:36912-36920.

19. Moerland M, Samyn H, van Gent T, van Haperen R, Dallinga-Thie G, Grosveld F, van Tol A, de Crom R: Acute elevation of plasma PLTP activity strongly increases pre-existing atherosclerosis. Arterioscler Thromb Vasc Biol 2008, 28:1277-1282.

20. Lie J, de Crom R, van Gent T, van Haperen R, Scheek L, Lankhuizen I, van Tol A: Elevation of plasma phospholipid transfer protein in transgenic mice increases VLDL secretion. J Lipid Res 2002, 43:1875-1880.

21. van Haperen R, van Tol A, van Gent T, Scheek L, Visser P, van der Kamp A, Grosveld F, de Crom R: Increased risk of atherosclerosis by elevated plasma levels of phospholipid transfer protein. J Biol Chem 2002, 277:48938-48943.

22. Lie J, de Crom R, van Gent T, van Haperen R, Scheek L, Sadeghi-Niaraki F, van Tol A: Elevation of plasma phospholipid transfer protein increases the risk of atherosclerosis despite lower apolipoprotein B-containing lipoproteins. J Lipid Res 2004, 45:805-811.

23. Jiang XC, Tall AR, Qin S, Lin M, Schneider M, Lalanne F, Deckert V Desrumaux C, Athias A, Witztum JL, Lagrost L: Phospholipid transfer protein deficiency protects circulating lipoproteins from oxidation due to the enhanced accumulation of vitamin E. J Biol Chem 2002, 277:31850-31856.

24. Samyn H, Moerland M, van Gent $T$, van Haperen $R$, Grosveld F, van Tol A, de Crom R: Elevation of systemic PLTP, but not macrophage-PLTP, impairs macrophage reverse cholesterol transport in transgenic mice. Atherosclerosis 2009, 204:429-434

25. Samyn H, Moerland M, van Gent T, van Haperen R, Metso J, Grosveld F, Jauhiainen M, van Tol A, de Crom R: Plasma phospholipid transfer activity is essential for increased atherogenesis in PLTP transgenic mice: a mutation-inactivation study. J Lipid Res 2008, 49:2504-2512.

26. Jiang XC, Qin S, Qiao C, Kawano K, Lin M, Skold A, Xiao X, Tall AR: Apolipoprotein $B$ secretion and atherosclerosis are decreased in mice with phospholipid-transfer protein deficiency. Nat Med 2001, 7:847-752.

27. Hayek T, Azrolan N, Verdery RB, Walsh A, Chajek-Shaul T, Agellon LB, Tall AR, Breslow JL: Hypertriglyceridemia and cholesteryl ester transfer protein interact to dramatically alter high density lipoprotein levels, particle sizes, and metabolism. Studies in transgenic mice. J Clin Invest 1993, 92:1143-1152.

28. Föger B, Santamarina-Fojo S, Shamburek RD, Parrot CL, Talley GD, Brewer HB Jr: Plasma phospholipid transfer protein. Adenovirus- mediated overexpression in mice leads to decreased plasma high density lipoprotein (HDL) and enhanced hepatic uptake of phospholipids and cholesteryl esters from HDL. J Biol Chem 1997, 272:27393-27400.

29. Moerland M, Anghelescu N, Samyn H, van Haperen $R$, van Gent $T$, Strouboulis J, van Tol A, Grosveld F, de Crom R: Inducible expression of phospholipid transfer protein (PLTP) in transgenic mice: acute effects of PLTP on lipoprotein metabolism. Transgenic Res 2007, 16:503-513.

30. Yang XP, Yan D, Qiao C, Liu RJ, Chen JG, Li J, Schneider M, Lagrost L, Xiao $X$, Jiang XC: Increased atherosclerotic lesions in apoE mice with plasma phospholipid transfer protein overexpression. Arterioscler Thromb Vasc Biol 2003, 23:1601-1607.

31. Jiang XC, Li Z, Liu R, Yang XP, Pan M, Lagrost L, Fisher EA, Williams KJ: Phospholipid transfer protein deficiency impairs apolipoprotein-B secretion from hepatocytes by stimulating a proteolytic pathway through a relative deficiency of vitamin $E$ and an increase in intracellular oxidants. J Biol Chem 2005, 280:18336-18340.

doi:10.1186/1476-511X-9-114

Cite this article as: Liu et al:: Low cholesteryl ester transfer protein and phospholipid transfer protein activities are the factors making tree shrew and beijing duck resistant to atherosclerosis. Lipids in Health and Disease 2010 9:114.

\section{Submit your next manuscript to BioMed Central and take full advantage of:}

- Convenient online submission

- Thorough peer review

- No space constraints or color figure charges

- Immediate publication on acceptance

- Inclusion in PubMed, CAS, Scopus and Google Scholar

- Research which is freely available for redistribution

Submit your manuscript at www.biomedcentral.com/submit
C Biomed Central 